\title{
Tellurium(IV) Complexes Containing Bidentate Schiff Base and their Biological Activities
}

\author{
ANJU MALIK, K.K.VERMA and SAPANA GARG* \\ Department of Chemistry, Maharshi Dayanand University, Rohtak-124001, India \\ sapanagarg1511@gmail.com
}

Received 29 September 2017 / Accepted 18 October 2017

\begin{abstract}
Monobasic $(O N)$ bidentate Schiff base ligand has been prepared by condensing $o$-hydroxybenzaldehyde with 3-aminopyridine. The new organyltellurium(IV) complexes, having formula $\left[\mathrm{TeCl}_{3}(3-\mathrm{APY}-\{\mathrm{Sal}\})\right],\left[\mathrm{RTeCl}_{2}(3-\mathrm{APY}-\{\mathrm{Sal}\})\right]$ and $\left[\mathrm{R}_{2} \mathrm{TeCl}(3-\mathrm{APY}-\{\mathrm{Sal}\})\right]$ have been synthesized by reacting equimolar ratio of Schiff base (3-APY- $\{\mathrm{SalH}\})$ with $\mathrm{TeCl}_{4}, \mathrm{RTeCl}_{3}$ and $\mathrm{R}_{2} \mathrm{TeCl}_{2}$ : where $\mathrm{R}=4$-methoxyphenyl, 4-hydroxyphenyl, 3-methyl-4-hydroxyphenyl. The characterization of Schiff base and its complexes were carried out by elemental analyses, conductivity measurements, FTIR and ${ }^{1} \mathrm{H}$ NMR spectral studies. Also, the biological activities (antifungal and antibacterial) of the Schiff base ligand and some of its tellurium(IV) complexes have been studied.
\end{abstract}

Keywords: Schiff base complexes, Monobasic, Bidentate, $o$-Hydroxybenzaldehyde, 3-Aminopyridine.

\section{Introduction}

Schiff bases are the condensation product of carbonyl groups (aldehydes or ketones) with amine ${ }^{1,2}$. Schiff base ligands are considered to be good chelating agents and -OH functional group close to azomethine group made them as special class of ligands ${ }^{3-6}$. Some Schiff bases are reported to possess antibacterial ${ }^{1,7-12}$, antifungal ${ }^{9-13}$ and antitumor activities ${ }^{14,15}$. It is reported ${ }^{1,16}$ in the literature that heteroatom increases the Schiff base activity and also Schiff bases derived from substituted $o$-hydroxybenzaldehyde exhibit more antimicrobial activity ${ }^{17,18}$. Literature survey reveals that a number of metal complexes of Schiff bases derived from 2-aminopyridine and 2,3-diaminopyridine with $o$-hydroxybenzaldehyde, $p$-hydroxybenzaldehyde and $p$-nitrobenzaldehyde etc., have been reported to possess antimicrobial activity ${ }^{19-30}$.

Tellurium(IV) chloride is also known to form adducts with amides ${ }^{31-38}$ and thiourea ${ }^{39}$, thus reflecting its acceptor behaviour. Also, organyltellurium(IV) chlorides are known ${ }^{31-36,40-56}$ to behave as Lewis acids and form complexes with several N-, O- and S- donor bases. In view of this, we have investigated the reactions of tellurium(IV) chloride and organyltellurium(IV) chlorides with $o$-hydroxybenzaldehyde-3-aminopyridine Schiff base (3-APY- $\{\mathrm{SalH}\})$, to synthesize some new complexes of tellurium(IV). 


\section{Experimental}

All chemicals used were of analytical reagent grade. All preparations were carried out under an atmosphere of dry $\mathrm{N}_{2}$ atmosphere. The solvents were purified by standard method ${ }^{57,58}$ before use. The purity of compounds was checked by TLC using Silica gel-G (Merck). Melting points were determined in open capillary tube and are uncorrected.

Carbon, hydrogen and nitrogen analyses were obtained microanalytically from SAIF, Panjab University Chandigarh on a ThermoFinnigan CHNS analyser. Conductivity was measured in DMSO at $25 \pm 2{ }^{\circ} \mathrm{C}$ with a dip type conductivity cell on a microprocessor based conductivity bridge type MICROSIL.

Infrared spectra (4000-40 $\mathrm{cm}^{-1}$ ) were recorded in $\mathrm{KBr}$ and Polyethylene pellets for MidIR and Far-IR respectively, on a FT-Infra-Red Spectrometer Model Nicolet IS50 (Thermo Scientific). Proton NMR Spectra were recorded in DMSO- $\mathrm{d}_{6}$ using tetramethylsilane as an internal reference on BRUKER AVANCE II 400 NMR spectrometer from CIL, Guru Jambeshwar University of Science and Technology, Hissar, Haryana, India.

Preparation of organyltellurium(IV) trichlorides and diorganyltellurium(IV) dichlorides 4-Methoxyphenyltellurium(IV) $\quad$ trichloride $^{59,60}, \quad$ bis(p-methoxyphenyl)tellurium(IV) dichloride $^{60,61}$, 4-hydroxyphenyltellurium(IV) trichloride ${ }^{62}$, bis(p-hydroxyphenyl) tellurium(IV) dichloride $^{62}$, 3-methyl-4-hydroxyphenyltellurium(IV) trichloride ${ }^{63}$ and bis(3-methyl-4hydroxyphenyl)tellurium(IV) dichloride ${ }^{63}$ were prepared by the reactions of tellurium tetrachloride (Aldrich) with corresponding arenes i.e. anisole, phenol, o-cresol respectively, by the methods reported in the literature ${ }^{59-63}$.

\section{Preparation of o-Hydroxybenzaldehyde-3-Aminopyridine Schiff base (3-APY- $\{\mathrm{SalH}\})$}

The Schiff base was prepared by mixing equimolecular quantity of $o$-hydroxybenzaldehyde $(0.08$ mole, $9.76 \mathrm{~g})$ and 3-aminopyridine $(0.08$ mole, $7.52 \mathrm{~g})$ in $10 \mathrm{~mL}$ methanol in a round bottomed flask equipped with a condenser ${ }^{64}$. The reaction mixture was refluxed on water bath for 4 hours. After completion of reaction, the reaction mixture was cooled, filtered and dried in a desiccator over anhydrous $\mathrm{CaCl}_{2}$ and recrystallized from methanol, a sharp yellowish orange crystalline product was obtained.

\section{Preparation of complexes}

Tellurium tetrachloride, organyltellurium(IV) trichlorides and diorganyltellurium(IV) dichlorides, when reacted with Schiff base (3-APY- $\{\mathrm{SalH}\}$ ) form solid complexes as described below:

\section{$\left[\mathrm{TeCl}_{3}(3-\mathrm{APY}-\{\mathrm{Sal}\})\right],\left[R T e C l_{2}(3-A P Y-\{\mathrm{Sal}\})\right]$ and $\left[\mathrm{R}_{2} \mathrm{TeCl}(3-\mathrm{APY}-\{\mathrm{Sal}\})\right]$}

The solid complexes were prepared by addition of $5 \mathrm{mmol}$ tellurium(IV) derivatives in about $25 \mathrm{~mL}$ anhydrous methanol to a hot solution of $5 \mathrm{mmol}$ Schiff base $(3-\mathrm{APY}-\{\mathrm{SalH}\})$ in about $25 \mathrm{~mL}$ methanol with continuous stirring. The reaction mixture was refluxed on steam bath for 4 hours. The excess solvent was distilled off to obtain the desired products which were recrystallized from dry methanol. The coloured complexes crystallized out, which were filtered, washed with dry methanol and dried in a vacuum desiccator over $\mathrm{P}_{4} \mathrm{O}_{10}$.

\section{Results and Discussion}

$\mathrm{TeCl}_{4}$ when heated with anisole ${ }^{59-61}$, phenol ${ }^{62}$ and $o$-cresol ${ }^{63}$ (R-H) appears to undergo the Friedel Craft type condensation reaction where by $\mathrm{TeCl}_{3}{ }^{+}$unit attacks a position para to the 
methoxy/hydroxyl group in the aromatic ring, thus resulting in the formation of organyltellurium(IV) trichlorides and diorganyltellurium(IV) dichlorides.

$$
\begin{array}{r}
\mathrm{R}-\mathrm{H}+\mathrm{TeCl}_{4} \longrightarrow \mathrm{RTeCl}_{3}+\mathrm{HCl} \\
2 \mathrm{R}-\mathrm{H}+\mathrm{TeCl}_{4} \longrightarrow \mathrm{R}_{2} \mathrm{TeCl}_{2}+2 \mathrm{HCl}
\end{array}
$$

Preparation of Schiff Base (3-APY- $\{\mathrm{SalH}\})$, by the reaction of $o$-hydroxybenzaldehyde with 3-aminopyridine can be represented by following equation.<smiles>O=Cc1ccccc1O</smiles><smiles>Nc1cccnc1</smiles><smiles>Oc1ccccc1/C=N/c1cccnc1</smiles>

$o$-Hydroxybenzaldehyde 3-aminopyridine

(3-APY- $\{\mathrm{SalH}\})$

Schiff Base reacts with tellurium(IV) chloride, organyltellurium(IV) trichlorides and diorganyltellurium(IV) dichlorides to yield the coloured tellurium(IV) complexes.

$$
\begin{aligned}
\mathrm{TeCl}_{4}+(3-\mathrm{APY}-\{\mathrm{SalH}\}) & \longrightarrow \mathrm{TeCl}_{3}(3-\mathrm{APY}-\{\mathrm{Sal}\}) \\
\mathrm{RTeCl}_{3}+(3-\mathrm{APY}-\{\mathrm{SalH}\}) & \longrightarrow \mathrm{RTeCl}_{2}(3-\mathrm{APY}-\{\mathrm{Sal}\}) \\
\mathrm{R}_{2} \mathrm{TeCl}_{2}+(3-\mathrm{APY}-\{\mathrm{SalH}\}) & \longrightarrow \mathrm{R}_{2} \mathrm{TeCl}(3-\mathrm{APY}-\{\mathrm{SalH}\})
\end{aligned}
$$

All the tellurium(IV) complexes are colored, crystalline solids, stable at room temperature and non-hygroscopic in nature. They are insoluble in non polar and less polar organic solvents, but are soluble in polar donor solvents like DMF, DMSO etc. The analytical data along with their physical properties are presented in Table 1.

\section{Conductance studies}

Molar conductance $\left(\Lambda_{\mathrm{M}}\right)$ data for organyltellurium(IV) Schiff base complexes in DMSO are compiled in Table 1. The $\Lambda_{\mathrm{M}}$ values at $c a \cdot 10^{-3} \mathrm{M}$ of complexes lies in the range 10.52-36.78 $\mathrm{S} \mathrm{cm} \mathrm{mol}^{-1}$ which predict the non-electrolyte to $1: 1$ weak electrolyte type behavior ${ }^{65,66}$ of these Schiff base complexes in DMSO, probably due to ionization into $\mathrm{TeCl}_{2}(3$-APY$\{\mathrm{Sal}\})^{+} / \mathrm{RTeCl}(3-\mathrm{APY}-\{\mathrm{Sal}\})^{+} / \mathrm{R}_{2} \mathrm{Te}(3-\mathrm{APY}-\{\mathrm{Sal}\})^{+}$and $\mathrm{Cl}^{-}$in DMSO. The higher $\Lambda_{\mathrm{M}}$ values for some complexes may be due to steric factors and donor behavior of DMSO to result in probable dissociation into solvated cation and 3-APY- $\{\mathrm{Sal}\}$ along with $\mathrm{Cl}^{-}$in DMSO. This conductance behavior of tellurium(IV) Schiff base complexes is different from those of transition metal complexes ${ }^{67}$ which are reported to be non-electrolytes.

\section{Infrared spectra}

The IR spectral data (Table 2) of Schiff base and its complexes with organyltellurium(IV) chlorides are compared in order to determine the coordination sites involved in the chelation. The vibrational spectra of the ligand exhibit the characteristic bands ${ }^{2,37,64,68}$, one at $1619 \mathrm{~cm}^{-1}$ of azomethine $v_{(\mathrm{C}=\mathrm{N})}$ group and another at $3052 \mathrm{~cm}^{-1}$, of phenolic $v_{(\mathrm{OH})}$ group. While in the complexes $v_{(\mathrm{C}=\mathrm{N})}$ bands were shifted to lower frequency region ${ }^{2,13,64,68,69,70}$ i.e. $1605-1613 \mathrm{~cm}^{-1}$ indicating a decrease in the $\mathrm{C}=\mathrm{N}$ bond strength due to the formation of coordinate bond of the metal with the imine nitrogen lone pair ${ }^{71,72}$. The absence of peak due to the phenolic -OH group in free ligand at $3052 \mathrm{~cm}^{-1}$ in the complexes suggests the coordination of ligand to the metal through phenolic oxygen via deprotonation which infers that azomethine nitrogen and phenolic oxygen are the coordination sites of bidentate ligand. Also, the appearance of new strong bands around ${ }^{69,70,73,74}$ at $289-295 \mathrm{~cm}^{-1}$ due to $v_{(\mathrm{Te}-\mathrm{O})}$ and in the range of $414-419 \mathrm{~cm}^{-1} \mathrm{due}^{75}$ to $v_{(\mathrm{Te}-\mathrm{N})}$ further support the involvement of phenolic oxygen and azomethine nitrogen atom of Schiff base in the coordination. 
Table 1. Analytical data, molar conductance and physical properties for Schiff base (3-APY- $\{$ SalH $\})$ complexes of tellurium(IV) values of $\Lambda_{\mathrm{M}}$ reported $^{65,66}$ for $1: 1$ electrolytes in DMSO $=50-70 \mathrm{~S} \mathrm{~cm}^{2} \mathrm{~mol}^{-1}$

\begin{tabular}{|c|c|c|c|c|c|c|c|c|c|c|}
\hline \multirow{2}{*}{$\begin{array}{l}\text { Compd. } \\
\text { No. }\end{array}$} & \multirow{2}{*}{$\begin{array}{l}\text { Complex } \\
\text { (R) }\end{array}$} & \multirow{2}{*}{$\begin{array}{l}\text { Empirical formula } \\
\text { (Formula Wt.) }\end{array}$} & \multirow{2}{*}{$\begin{array}{l}\text { Colour, } \\
\text { Yield, \% }\end{array}$} & \multirow{2}{*}{$\begin{array}{l}\text { M. Pt. } \\
{ }^{\circ} \mathrm{C}, \text { dec. }\end{array}$} & \multicolumn{5}{|c|}{ Analyses \% Found (Calculated) } & \multirow{2}{*}{$\begin{array}{c}\Lambda_{\mathrm{M}} \text { at } c a \cdot 10^{-3} \mathrm{M} \\
\mathrm{S} \mathrm{cm}^{2} \mathrm{~mol}^{-1} \\
\text { in DMSO }\end{array}$} \\
\hline & & & & & $\mathrm{C}$ & $\mathrm{H}$ & $\mathrm{N}$ & $\mathrm{Te}$ & $\mathrm{Cl}$ & \\
\hline $\begin{array}{l}\text { Schiff } \\
\text { Base }\end{array}$ & (3-APY- $\{$ SalH $\})$ & $\begin{array}{c}\mathrm{C}_{12} \mathrm{H}_{10} \mathrm{~N}_{2} \mathrm{O} \\
(198.24)\end{array}$ & $\begin{array}{c}\text { Yellowish } \\
\text { Orange (94) }\end{array}$ & $66-68$ & $\begin{array}{c}72.48 \\
(72.70)\end{array}$ & $\begin{array}{c}5.25 \\
(5.09)\end{array}$ & $\begin{array}{r}14.02 \\
(14.13)\end{array}$ & - & - & - \\
\hline 1 & $\mathrm{TeCl}_{3}(3-\mathrm{APY}-\{\mathrm{Sal}\})$ & $\begin{array}{c}\mathrm{C}_{12} \mathrm{H}_{9} \mathrm{Cl}_{3} \mathrm{~N}_{2} \mathrm{OTe} \\
(431.33)\end{array}$ & $\begin{array}{c}\text { Dark } \\
\text { Orange }(71)\end{array}$ & $182-184$ & $\begin{array}{c}34.72 \\
(34.87)\end{array}$ & $\begin{array}{c}2.38 \\
(2.11)\end{array}$ & $\begin{array}{c}6.35 \\
(6.50)\end{array}$ & $\begin{array}{c}29.42 \\
(29.58)\end{array}$ & $\begin{array}{c}24.57 \\
(24.69)\end{array}$ & 11.23 \\
\hline 2 & $\begin{array}{c}\mathrm{RTeCl}_{2}(3-\mathrm{APY}-\{\mathrm{Sal}\}) \\
\text { (4-methoxyphenyl) }\end{array}$ & $\begin{array}{c}\mathrm{C}_{19} \mathrm{H}_{16} \mathrm{Cl}_{2} \mathrm{~N}_{2} \mathrm{O}_{2} \mathrm{Te} \\
(502.97)\end{array}$ & $\begin{array}{c}\text { Reddish } \\
\text { Brown (83) }\end{array}$ & $137-139$ & $\begin{array}{c}45.12 \\
(45.37)\end{array}$ & $\begin{array}{c}3.34 \\
(3.21)\end{array}$ & $\begin{array}{c}5.35 \\
(5.57)\end{array}$ & $\begin{array}{c}25.18 \\
(25.37)\end{array}$ & $\begin{array}{c}13.87 \\
(14.12)\end{array}$ & 17.11 \\
\hline 3 & $\begin{array}{c}\mathrm{RTeCl}_{2}(3-\mathrm{APY}-\{\mathrm{Sal}\}) \\
\text { (4-hydroxyphenyl) }\end{array}$ & $\begin{array}{c}\mathrm{C}_{18} \mathrm{H}_{14} \mathrm{Cl}_{2} \mathrm{~N}_{2} \mathrm{O}_{2} \mathrm{Te} \\
(488.94)\end{array}$ & $\begin{array}{c}\text { Dark } \\
\text { Brown (77) }\end{array}$ & $171-173$ & $\begin{array}{c}44.05 \\
(44.21)\end{array}$ & $\begin{array}{c}2.97 \\
(2.89)\end{array}$ & $\begin{array}{c}5.58 \\
(5.73)\end{array}$ & $\begin{array}{c}26.32 \\
(26.10)\end{array}$ & $\begin{array}{c}14.38 \\
(14.52)\end{array}$ & 16.38 \\
\hline 4 & $\begin{array}{c}\mathrm{RTeCl}_{2}(3-\mathrm{APY}-\{\mathrm{Sal}\}) \\
\text { (3-methyl-4- } \\
\text { hydroxyphenyl) }\end{array}$ & $\begin{array}{c}\mathrm{C}_{19} \mathrm{H}_{16} \mathrm{Cl}_{2} \mathrm{~N}_{2} \mathrm{O}_{2} \mathrm{Te} \\
(502.97)\end{array}$ & $\begin{array}{c}\text { Dark } \\
\text { Yellow }(85)\end{array}$ & $207-209$ & $\begin{array}{c}45.12 \\
(45.37)\end{array}$ & $\begin{array}{c}3.42 \\
(3.21)\end{array}$ & $\begin{array}{c}5.35 \\
(5.57)\end{array}$ & $\begin{array}{c}25.18 \\
(25.37)(\end{array}$ & $\begin{array}{c}13.96 \\
(14.12)\end{array}$ & 10.52 \\
\hline 5 & $\begin{array}{l}\mathrm{R}_{2} \mathrm{TeCl}(3-\mathrm{APY}-\{\mathrm{Sal}\}) \\
\quad(4-\text { methoxyphenyl) }\end{array}$ & $\begin{array}{c}\mathrm{C}_{26} \mathrm{H}_{23} \mathrm{ClN}_{2} \mathrm{O}_{3} \mathrm{Te} \\
(574.61)\end{array}$ & $\begin{array}{l}\text { Light } \\
\text { Brown (73) }\end{array}$ & $218-220$ & $\begin{array}{c}54.21 \\
(54.34)\end{array}$ & $\begin{array}{c}4.17 \\
(4.04)\end{array}$ & $\begin{array}{c}4.71 \\
(4.88)\end{array}$ & $\begin{array}{c}22.46 \\
(22.21)\end{array}$ & $\begin{array}{c}6.02 \\
(6.18)\end{array}$ & 26.19 \\
\hline 7 & $\begin{array}{c}\mathrm{R}_{2} \mathrm{TeCl}(3-\mathrm{APY}-\{\mathrm{Sal}\}) \\
\text { (3-methyl-4- } \\
\text { hydroxyphenyl) }\end{array}$ & $\begin{array}{c}\mathrm{C}_{26} \mathrm{H}_{23} \mathrm{ClN}_{2} \mathrm{O}_{3} \mathrm{Te} \\
(574.61)\end{array}$ & $\begin{array}{l}\text { Light brown } \\
\qquad(80)\end{array}$ & $160-162$ & $\begin{array}{c}53.97 \\
(54.34)\end{array}$ & $\begin{array}{c}3.89 \\
(4.04)\end{array}$ & $\begin{array}{c}4.63 \\
(4.88)\end{array}$ & $\begin{array}{c}22.43 \\
(22.21)\end{array}$ & $\begin{array}{c}6.07 \\
(6.18)\end{array}$ & 33.36 \\
\hline
\end{tabular}


Further, presence of organyl groups of Rte and $\mathrm{R}_{2} \mathrm{Te}$ may result in mixing of certain bands, thus making independent assignments very difficult. Thus, the Schiff base ligand is coordinated to the tellurium atom as uninegative $O N$ bidentate ligand give rise to a six membered chelating ring with tellurium centre.

Table 2. Important IR data $\left(\mathrm{cm}^{-1}\right)$ of the Schiff Base (3-APY- $\left.\{\mathrm{SalH}\}\right)$ and complexes

\begin{tabular}{ccccc}
\hline $\begin{array}{c}\text { Compd } \\
\text { No. }\end{array}$ & $\begin{array}{c}\text { (Phenolic) } \\
\mathrm{V}_{(\mathrm{OH})}\end{array}$ & $\begin{array}{c}\text { (Azomethine) } \\
\mathrm{V}_{(\mathrm{C}=\mathrm{N})}\end{array}$ & $\mathrm{v}_{(\mathrm{Te}-\mathrm{O})}$ & $\mathrm{v}_{(\mathrm{Te}-\mathrm{N})}$ \\
\hline (3-APY- $\{$ SalH $\})$ & $3052 \mathrm{~s}$ & $1619 \mathrm{~s}$ & - & - \\
1 & - & $1605 \mathrm{~s}$ & $289 \mathrm{~s}$ & $419 \mathrm{~s}$ \\
2 & - & $1608 \mathrm{~s}$ & $292 \mathrm{~s}$ & $414 \mathrm{~s}$ \\
3 & - & $1607 \mathrm{~m}$ & $290 \mathrm{~s}$ & $419 \mathrm{~s}$ \\
4 & - & $1606 \mathrm{sh}$ & $294 \mathrm{~s}$ & $416 \mathrm{~s}$ \\
5 & - & $1609 \mathrm{~s}$ & $290 \mathrm{~s}$ & $419 \mathrm{~s}$ \\
6 & - & $1613 \mathrm{~s}$ & $290 \mathrm{~s}$ & $419 \mathrm{~s}$ \\
\hline
\end{tabular}

( $s=$ strong, $m=$ medium, $b=$ broad, $s h=$ shoulder $)$

\section{${ }^{1}$ H NMR spectra}

Further, evidence for the coordination mode of the ligand is obtained by ${ }^{1} \mathrm{H}$ NMR studies and chemical shift data for the free ligand (3-APY- $\{\mathrm{SalH}\})$ and its complexes are compiled in Table 3.

Table 3. ${ }^{1} \mathrm{H}$ NMR spectral data of Schiff base (3-APY- $\left.\{\mathrm{SalH}\}\right)$ and complexes in DMSO-d 6

\begin{tabular}{|c|c|c|c|c|c|}
\hline $\begin{array}{l}\text { Compd } \\
\text { No }\end{array}$ & $\begin{array}{l}\text { (Phenolic) } \\
\text {-OH } \delta \text { ppm }\end{array}$ & $\begin{array}{l}\text { (Azomethine) } \\
-\mathbf{H C}=\mathrm{N} \delta \mathrm{ppm}\end{array}$ & $\begin{array}{c}\text { (Ar rings } \\
\text { protons) } \delta \mathrm{ppm}\end{array}$ & $\begin{array}{c}-\mathrm{CH}_{3} /-\mathrm{OCH}_{3}{ }^{*} \\
\delta \mathrm{ppm}\end{array}$ & $\begin{array}{c}-\mathrm{OH} \text { of } \\
\mathrm{Rte}_{\mathrm{R}} \mathrm{Te} \\
\delta \mathrm{ppm}\end{array}$ \\
\hline (3-APY-SalH $\})$ & $\begin{array}{l}12.773 \\
(\mathrm{~s}, 1 \mathrm{H})\end{array}$ & $9.306(\mathrm{~s}, 1 \mathrm{H})$ & $\begin{array}{c}6.950-8.648 \\
(\mathrm{~cm}, 8 \mathrm{H})\end{array}$ & - & - \\
\hline 1 & - & $10.230(\mathrm{~s}, 1 \mathrm{H})$ & $\begin{array}{c}6.860-7.945 \\
(\mathrm{~cm}, 8 \mathrm{H})\end{array}$ & - & - \\
\hline 2 & - & $10.273(\mathrm{~s}, 1 \mathrm{H})$ & $\begin{array}{c}6.849-8.347 \\
(\mathrm{~cm}, 12 \mathrm{H})\end{array}$ & $\begin{array}{l}3.805 \\
\left(\mathrm{~s}, 3 \mathrm{H}^{*}\right)\end{array}$ & - \\
\hline 3 & - & $10.274(\mathrm{~s}, 1 \mathrm{H})$ & $\begin{array}{c}6.855-8.093 \\
(\mathrm{~cm}, 12 \mathrm{H})\end{array}$ & - & $\begin{array}{l}9.104 \\
(\mathrm{~s}, 1 \mathrm{H})\end{array}$ \\
\hline 4 & - & $10.234(\mathrm{~s}, 1 \mathrm{H})$ & $\begin{array}{c}7.040-8.347 \\
(\mathrm{~cm}, 11 \mathrm{H})\end{array}$ & $2.508(\mathrm{~s}, 3 \mathrm{H})$ & $\begin{array}{l}9.088 \\
(\mathrm{~s}, 1 \mathrm{H})\end{array}$ \\
\hline 5 & - & $10.273(\mathrm{~s}, 1 \mathrm{H})$ & $\begin{array}{c}6.841-8.231 \\
(\mathrm{~cm}, 16 \mathrm{H})\end{array}$ & $\begin{array}{c}3.432 \\
\left(\mathrm{~s}, 6 \mathrm{H}^{*}\right)\end{array}$ & - \\
\hline 6 & - & $10.148(\mathrm{~s}, 1 \mathrm{H})$ & $\begin{array}{c}7.620-8.729 \\
(\mathrm{~cm}, 16 \mathrm{H}) \\
\end{array}$ & - & $\begin{array}{l}9.098 \\
(\mathrm{~s}, 2 \mathrm{H})\end{array}$ \\
\hline
\end{tabular}

$s=$ singlet, $\mathrm{cm}=$ complex multiplet

The ligand is characterized by three signals at 12.773 (singlet), 9.306 (singlet) and 6.950-8.648 (complex multiplet) $\delta \mathrm{ppm}$ which are assigned to phenolic $-\mathrm{OH}$, azomethine proton $-\mathrm{N}=\mathrm{CH}$ - and aromatic as well as pyridine protons respectively.

The presence of $-\mathrm{N}=\mathrm{CH}$ - proton signal at $9.306 \delta \mathrm{ppm}$ in the ligand confirms the formation of base by condensation of $o$-hydroxybenzaldehyde with 3-aminopyridine. The azomethine proton signal in the complexes i.e. $\left[\mathrm{TeCl}_{3}(3-\mathrm{APY}-\{\mathrm{Sal}\})\right],\left[\mathrm{RTeCl}_{2}(3-\mathrm{APY}-\{\mathrm{Sal}\})\right]$ 
and $\left[\mathrm{R}_{2} \mathrm{TeCl}(3-\mathrm{APY}-\{\mathrm{Sal}\})\right]$, shows downfield shifting as compared to free ligand, suggesting deshielding of azomethine proton due to cooedination to tellurium through the azomethine nitrogen ${ }^{48,49,68,76}$.

Also the absence of proton signal at $12.773 \delta \mathrm{ppm}$ indicating that phenolic proton is absent in complexes and confirms the participation of -OH group of $o$-hydroxybenzaldehyde in the coordination via deprotonation.

Independent assignments to the aryl protons of (3-APY- $\{\mathrm{SalH}\})$ and RTe / $\mathrm{R}_{2} \mathrm{Te}$ are not possible due to overlapping of signals in this region. On the basis of spectral studies, it may be concluded that $(3-\mathrm{APY}-\{\mathrm{SalH}\})$ acts as uninegative $(O N)$ bidentate ligand, resulting in the formation of pentacoordinated tellurium(IV) complexes and proposed structures are shown in Figure 1.<smiles>Oc1ccccc1/C=N/c1cccnc1</smiles>

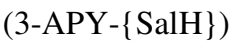<smiles>[R][Te]1(Cl)CN(c2cccnc2)C=Cc2ccccc2O1</smiles>

$\mathrm{RTeCl}_{2}(3-\mathrm{APY}-\{\mathrm{Sal}\})$<smiles>Cl[Te](Cl)(Cl)CN1C=Cc2ccccc2O1</smiles>

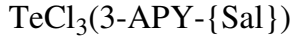<smiles>[R][Te]([R])(Cl)[C]1N=Cc2ccccc2O1</smiles>

$\mathrm{R}_{2} \mathrm{TeCl}(3-\mathrm{APY}-\{\mathrm{Sal}\})$

Figure 1. Proposed structures of Schiff base (3-APY- $\{\mathrm{SalH}\}$ ) and tellurium (IV) complexes Biological studies

The $o$-hydroxybenzaldehyde-3-aminopyridine Schiff base (3-APY- $\{\mathrm{SalH}\}$ ) and newly synthesized organyltellurium(IV) Schiff base complexes were evaluated for their antimicrobial activities in vitro against Gram-positive bacteria (Staphylococcus aureus MTCC 96 and Streptococcus pyogenes MTCC 442), Gram-negative bacteria (Pseudomonas aeruginosa MTCC 1688 and Escherichia coli MTCC 443) and fungi Candida albicans MTCC 227, Aspergillus niger MTCC 282 and Aspergillus clavatus MTCC 1323. The evaluation of the biological activities was carried by "Broth Dilution Method". The MIC of the control organism is read to check the accuracy of the drug concentrations. The lowest concentration inhibiting growth of the organism is recorded as the MIC. The MIC values of ligand and the complexes have been compared with standard drugs ampicillin and chloramphenicol for antibacterial, nystatin and greseofulvin for antifungal activities ${ }^{77}$ are given in Table 4.

The data show the complexes of organyltellurium(IV) exhibit more antibacterial activity than antifungal activity as compared to free ligand. The complex no. 3 i.e. $\left[\mathrm{RTeCl}_{2}(3-\mathrm{APY}-\right.$ $\{$ Sal $\})]$ : where $\mathrm{R}=4$-hydroxyphenyl, shows substantial activity against all four bacterial strain than Schiff base itself. Most of the complexes are moderately more effective against fungal strain $C$. albicans MTCC 227 as compare to free ligand. 
Table 4. Minimum inhibitory concentration MIC ( $\mu \mathrm{g} / \mathrm{mL})$ of Schiff Base (3-APY- $\{\mathrm{SalH}\})$ and complexes

\begin{tabular}{cccccccc}
\hline & \multicolumn{4}{c}{ Bacterial Strain } & \multicolumn{3}{c}{ Fungal Strain } \\
\cline { 2 - 8 } Compd No & $S$. & \multicolumn{1}{c}{ S. } & $P$. & $E$. & $C$. & $A$. & $A$. \\
& aureus & pyogenes & aeruginosa & coli & albicans & niger & clavatus \\
& MTCC & MTCC & MTCC & MTCC & MTCC & MTCC & MTCC \\
& 96 & 442 & 1688 & 443 & 227 & 282 & 1323 \\
\hline$(3-$ APY- $\{$ SalH $\})$ & 500 & 250 & 250 & 250 & $>1000$ & 200 & 500 \\
1 & 250 & 250 & 500 & 500 & $>1000$ & $>1000$ & $>1000$ \\
2 & 200 & 250 & 250 & 200 & $\mathbf{5 0 0}$ & 1000 & 1000 \\
3 & $\mathbf{1 2 5}$ & $\mathbf{1 2 5}$ & $\mathbf{1 0 0}$ & $\mathbf{1 2 5}$ & $\mathbf{5 0 0}$ & 1000 & 1000 \\
6 & 200 & 250 & 250 & 200 & $\mathbf{2 5 0}$ & 500 & 500 \\
& Standard Drugs & & & & & \\
Ampicillin & 250 & 100 & 100 & 100 & - & - & - \\
Chloramphenicol & 50 & 50 & 50 & 50 & - & - & - \\
Nystatin & - & - & - & - & 100 & 100 & 100 \\
Greseofulvin & - & - & - & - & 500 & 100 & 100 \\
\hline
\end{tabular}

\section{Conclusion}

The Schiff base (3-APY- $\{\mathrm{SalH}\}$ ) has been prepared by condensation of o-hydroxybenzaldehyde with 3-aminopyridine. Schiff base when reacted with tellurium tetrachloride, organyltellurium(IV) trichlorides and diorganyltellurium(IV) dichlorides in 1:1 molar ratios yield $\left[\mathrm{TeCl}_{3}(3-\mathrm{APY}-\{\mathrm{Sal}\})\right]$, $\left[\mathrm{RTeCl}_{2}(3-\mathrm{APY}-\{\mathrm{Sal}\})\right]$ and $\left[\mathrm{R}_{2} \mathrm{TeCl}(3-\mathrm{APY}-\{\mathrm{Sal}\})\right]$ : where $\mathrm{R}=4$ methoxyphenyl, 4-hydroxyphenyl, 3-methyl-4-hydroxyphenyl type complexes. Spectral studies predict the pentacoordinated tellurium centre by the monobasic bidentate $(O N)$ Schiff base. Some of these complexes possess substantial antimicrobial activity.

\section{Acknowledgement}

The authors are grateful to M. D. University, Rohtak for providing the necessary facilities. One of the authors (AM) is also thankful to HSCST, Haryana for providing a fellowship. We also thank SAIF, Panjab University Chandigarh for providing the CHN analyses, ${ }^{1} \mathrm{H}$ NMR spectral data from CIL, Guru Jambeshwar University of Science and Technology, Hissar and the Microcare Laboratory, Surat, for providing antimicrobial activities.

\section{References}

1. Lei Shi, Hui-Ming Ge, Shu-Hua Tan, Huan-Qui Li, Yong-Chun Song, Hai-Liang Zhu and Ren-Xiang Tan, Eur J Med Chem., 2007, 42(4), 558-564;

DOI:10.1016/j.ejmech.2006.11.010

2. Chetana P R, Sahana S, Policegoudra R S and Aradhya S, Ind J Pharm Sci Res., 2016, 6(1), 18-26.

3. Canpolat E and Kaya M, Russ J Coord Chem., 2005, 31(11), 790-794;

DOI:10.1007/s11173-005-0170-7

4. Booysena I N, Maikoa S, Akermana M P, Xulua B and Murno O, J Coord Chem., 2013, 66(20), 3673-3685.

5. Barwiolek M, Szlyk E, Surdykowski A and Wojtczak A, Dalton Trans., 2013, 42, 11476-11487; DOI:10.1039/C3DT50213A

6. Fernandez G M, Portilla F R, Garcoa B Q, Toscano R A and Salcedob R, J Mol Struct., 2001 561(1-3), 197-207; DOI:10.1016/S0022-2860(00)00915-7 
7. Sridhar S K, Saravanan M and Ramesh A, Eur J Med Chem., 2001, 36(7-8), 615-625; DOI:10.1016/S0223-5234(01)01255-7

8. Mladenova R, Ignatova M, Manolova N, Petrova T and Rashkov I, Eur Polym J., 2002, 38(5), 989-999; DOI:10.1016/S0014-3057(01)00260-9

9. Panneerselvem P, Nair R R, Vijayalakshmi G, Subramanian E H and Sridhar S K, Eur J Med Chem., 2005, 40(2), 225-229; DOI:10.1016/j.ejmech.2004.09.003

10. Walsh O M, Meegan M J, Prendergast R M and Nakib T A, Eur J Med Chem., 1996, 31, 989-1000; DOI:10.1016/j.ejmech.2004.09.003

11. Pandeya S N, Sriram D, Nath G and DeClercq E, Eur J Pharm., 1999, 9(1), 25-31; DOI:10.1016/S0928-0987(99)00038-X

12. Pandeya S N, Sriram D, Nath G and DeClercq E, Pharm Acta Helv., 1999, 74(1), 11-17; DOI:10.1016/S0031-6865(99)00010-2

13. Ramesh R and Maheswaran S, J Inorg Biochem., 2003, 96(4), 457-462; DOI:10.1016/S0162-0134(03)00237-X

14. Liu M C, Lin T S and Sartorelli A C, J Med Chem., 1992, 35(20), 3672-3677; DOI:10.1021/jm00098a012

15. Hodnett E M and Dunn J W, J Med Chem., 1970, 13(4), 768-770; DOI:10.1021/jm00298a054

16. Gupta V, Singhand S and Gupta Y K, Res J Chem Sci., 2013, 3(9), 26-29.

17. Felton L C and Brewer J H, Science, 1947, 105, 409-410.

18. Byoke M S and Gulya A P, Pharm Chem J., 2005, 39, 30-32.

19. Jeewoth T, Bhowon M G and Li Kam Wah H, Trans Met Chem., 1999, 24(4), 445448; DOI:10.1023/A\%3A1006917704209

20. Cimerman Z, Galic N and Bosner B, Anal Chim Acta., 1997, 343(1-2), 145-152; DOI:10.1016/S0003-2670(96)00587-9

21. Dubey P K and Ratnam C V, Proc Indian Acad Sci., 1977, 85A, 204; DOI:10.1007/BF03049482

22. Cimerman Z, Galesic N and Bosner B, J Mol Stru., 1992, 274, 131-144; DOI:10.1016/0022-2860(92)80152-8

23. Cushman M, Wong W C and Bacher A, J Chem Soc Perkin Trans., 1986, 1, 1043 1050; DOI:10.1039/P19860001043

24. Mellor J M, Stibbard J H A and Rawlins M F, J Chem Soc Chem Comm., 1978, 557558; DOI:10.1039/C39780000557

25. Zecchini G P, Torrini I and Paradisi M P, J Heterocyclic Chem., 1985, 22(4), 10611064; DOI:10.1002/jhet.5570220427

26. Press J B, Hofmann C M, Wiegand G E and Safir S R, J Heterocyclic Chem., 1982, 19(2), 391-394; DOI:10.1002/jhet.5570190235

27. Essassi E M, Zniber R, Bernardini A and Viallefont P H, J Heterocyclic Chem., 1983, 20, 1015-1018; DOI:10.1002/jhet.5570200434

28. Robertson D W, Beedle E E, Krushinski J H, Pallock G D, Wilson H, Wyss V L and Hayes J S, J Med Chem., 1985, 28(6), 717-727; DOI:10.1021/jm00383a006

29. Israel $\mathrm{M}$ and Jones L C, J Heterocyclic Chem., 1973, 10(2), 201-207; DOI:10.1002/jhet.5570100213

30. Middleton R W and Wibberley D G, J Heterocyclic Chem., 1980, 17, 1757-1760; DOI:10.1002/jhet.5570170824

31. Goyat G, Garg S and Verma K K, Chem Sci Trans., 2016, 5(2), 479-487; DOI:10.7598/cst2016.1204

32. Goyat G, Garg S and Verma K K, Res J Pharm Biol Chem Sci., 2016, 7(2), 869-877. 
33. Goyat G, Malik A, Garg S and Verma K K, Int J Chem Sci., 2016, 14(3), 1498-1510.

34. Goyat G, Malik A, Garg S and Verma K K, J Chem Pharm Res., 2016, 8(4), 218-223.

35. Goyat G, Malik A, Garg S and Verma K K, Int J Chem Sci., 2016, 14(1), 387-398.

36. Goyat G, Malik A, Garg S and Verma K K, Der Pharma Chemica, 2016, 8(2), 198-203.

37. Malhotra K C and Paul K K, Curr Sci., 1969, 38, 266.

38. Peirier M and Vincontini, Anal Acad Brazil Cinene, 1971, 43, 119.

39. Aynsley E E and Campbell W A, J Chem Soc., 1958, 3290-3293; DOI:10.1039/JR9580003290

40. Wynne K J and Pearson P S, Inorg Chem., 1971, 10(12), 2735-2739; DOI:10.1021/ic50106a022

41. Wynne K J and Pearson P S, J Chem Soc Chem Commun., 1970, 556.

42. Wynne K J, Clark A J and Berg M, J Chem Soc Dalton Trans., 1972, 2370-2374; DOI:10.1039/DT9720002370

43. Clark E R, Collet A J and Naik D G, J Chem Soc Dalton, 1973, 1961-1974; DOI:10.1039/B003985N

44. Berg M C, Diss Abstr Int., 1972, 33, 2982.

45. Srivastava T N, Singh M and Singh H B, Indian J Chem., 1982, 21A, 307-309.

46. Srivastava T N, Srivastava R C and Srivastava M, Indian J Chem., 1982, 21A, 539.

47. Srivastava T N, Srivastava R C and Srivastava V K, J Indian Chem Soc., 1983, 60(9), 891-892.

48. Garad M V, Polyhedron, 1985, 4(8), 1353-1355; DOI:10.1016/S0277-5387(00)86963-6

49. Verma K K and Reena, Synth React Inorg.Met-Org Chem., 1999, 29, 499-512.

50. Verma K K, Dahiya R and Soni D, Synth React Inorg Met-Org Chem., 1999, 29, 1033-1052.

51. Verma K K and Dahiya R, Synth React Inorg Met-Org Chem., 1999, 29, 1299-1314.

52. Verma K K and Reena, Phosphorus, Sulfur Silicon Related Elements, 1999, 148, 227 234; DOI:10.1080/10426509908037013

53. Verma K K and Seema, Int J Chem Sci., 2008, 6, 371-380.

54. Srivastava S, Soni D K and Gupta H S, J Indian Chem Soc., 1996, 73, 255.

55. Narwal J K, Chhabra S, Malik R K, Garg S and Verma K K, Oriental J Chem., 2013, 29(4), 1339-1349; DOI:10.13005/ojc/290409

56. Chhabra S and Verma K K, J Chem Pharm Res., 2010, 2(4), 569-575.

57. Vogel A I, A Test Book of Organic Chemistry, $3^{\text {rd }}$ Edn., Longman: London, 1975.

58. Weissberger A, Ed., Technique of Organic Chemistry, Vol. 7, $2^{\text {nd }}$ Edn., Interscience Publishers, Inc.: N. Y., 1967.

59. Morgan G T and Kellet R E, J Chem Soc., 1926, 129, 1080-1088; DOI:10.1039/JR9262901080

60. Petragnani $\mathrm{N}$ and Stefani $\mathrm{H}$ A, Tellurium in Organic Chemistry, $2^{\text {nd }}$ Edn., Academic Press: London, 2007, 76.

61. Bergman J, Tetrahedron, 1972, 28, 3323-3331; DOI:10.1016/S0040-4020(01)93674-9

62. Khandelwal B L, Kumar K and Berry F J, Inorg Chim Acta, 1981, 99(2), 135-137; DOI:10.1016/S0020-1693(00)89319-6

63. Khandelwal B L, Kumar K and Raina K, Synth React Inorg Met-Org Chem., 1981, 11(1), 65-78.

64. Abdel-Latif S A, Hassib H B and Issa Y M, Spectrochim Acta (A), 2007, 67(3-4), 950-957; DOI:10.1016/j.saa.2006.09.013

65. Geary W J, Coord Chem Rev., 1971, 7, 81-122; DOI:10.1016/S0010-8545(00)80009-0 
66. Greenwood N N, Straughan B P and Wilson A E, J Chem Soc A, 1968, 2209-2212; DOI:10.1039/J19680002209

67. Srivastava K P, Singh A and Singh S K, J Appl Chem., 2014, 7(4), 16-23; DOI:10.9790/5736-07411623

68. Dharmaraj N, Trans Metal Chem., 2001, 26(1-2), 105-109; DOI:10.1023/A\%3A1007132408648

69. Verma K K, Soni D and Verma S, Phosphorus, Sulfur Silicon, 2000, 166(1), 231-241; DOI:10.1080/10426500008076544

70. Pant B C, Mc Whinnie W R and Dance N S, J Organmetal Chem., 1973, 63, 305310; DOI:10.1016/S0022-328X(73)80043-9

71. Kohawole G A and Patel K S, J Chem Soc., Dalton Trans., 1981, 1241-1245; DOI:10.1039/DT9810001241

72. Gluvchinsky P and Moeler G M, Spectrochim Acta, 1973, 32(12), 1073-1077; DOI:10.1016/0584-8539(77)80156-6

73. Srivastava T N and Singh J D, Indian J Chem., 1987, 26A, 260.

74. Chauhan S, Garg S and Verma K K, Chem Sci Trans., 2016, 5(2), 431-441; DOI: $10.7598 /$ cst2016.1193

75. Kulkarni Y D, Srivastava S, Abdi S H R and Athar M, Synth React Inorg Met Org Chem., 1985, 15(8), 1043-1059.

76. Khera B, Sharma A K and Kaushik N K, Polyhedron, 1983, 2(11), 1177-1180; DOI:10.1016/S0277-5387(00)84353-3

77. Joshi K R, Rojivadiya A J and Pandya J H, Int J Inorg Chem., 2014, 10, 1155. 